\title{
Cyclosporine A attenuates apoptosis and necrosis after ischemia-reperfusion-induced renal injury in transiently hyperglycemic rats ${ }^{1}$
}

Sylvio Valença de Lemos Neto', Isabela Galvão Vianna", Yara Marcondes Machado Castiglia"I, Marjorie de Assis Golimv, Aparecida Vitória Gonçalves de Souzav, Lídia Raquel de Carvalhov", Elenice Deffune ${ }^{\mathrm{VII}}$, Paulo do Nascimento Junior ${ }^{\mathrm{VIII}}$, Norma Sueli Pinheiro Módolox ${ }^{\mathrm{IX}}$, Pedro Thadeu Galvão Vianna ${ }^{\mathrm{x}}$

'Fellow PhD degree, Postgraduate Program in Anesthesiology, Department of Anesthesiology, Botucatu Medical School, Universidade Estadual de São Paulo (UNESP), Botucatu-SP, Brazil. Conception and design of the study, acquisition of data, manuscript writing, critical revision.

"Fellow, Experimental Surgery, Department of Anesthesiology, Botucatu Medical School, UNESP, Botucatu-SP, Brazil. Manuscript writing.

IIIPhD, Full Professor, Department of Anesthesiology, Botucatu Medical School, UNESP, Botucatu-SP, Brazil. Critical revision, final approval of the version to be published.

IVPhD, Biologist, Department of Internal Medicine, Botucatu Medical School, UNESP, Botucatu-SP, Brazil. Technical procedures, histopathological examinations.

VFellow PhD degree, Postgraduate Program in Anesthesiology, Department of Anesthesiology, Botucatu Medical School, UNESP, Botucatu-SP, Brazil. Acquisition of data.

VIPhD, Assistant Professor, Department of Biostatistics, Bioscience Institute of Botucatu, UNESP, Botucatu-SP, Brazil. Statistical analysis. VIIPhD, Assistant Professor, Department of Internal Medicine, Botucatu Medical School, UNESP, Botucatu-SP, Brazil. Technical procedures, histopathological examinations.

VIIIPhD, Associate Professor, Department of Anesthesiology, Botucatu Medical School, UNESP, Botucatu-SP, Brazil. Manuscript preparation and writing, critical revision.

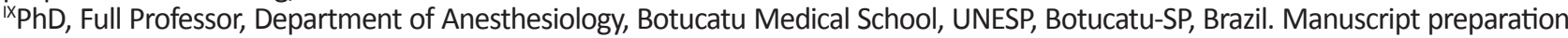
and writing, critical revision.

xPhD, Full Professor, Department of Anesthesiology, Botucatu Medical School, UNESP, Botucatu-SP, Brazil. Conception and design of the study, analysis and interpretation of data, critical revision, final approval of the version to be published.

\section{Abstract}

Purpose: To investigate the effects of cyclosporine A on renal ischemia-reperfusion injury during transient hyperglycemia in rats.

Methods: In a model of ischemia-reperfusion-induced renal injury and transiently induced hyperglycemia by intraperitoneal injection of glucose, $2.5 \mathrm{~g} . \mathrm{kg}^{-1}$, Wistar rats were anesthetized with either isoflurane or propofol and received intravenous cyclosporine A, $5 \mathrm{mg} \cdot \mathrm{kg}^{-1}$, five minutes before reperfusion. Comparison groups were isoflurane and propofol sham groups and isoflurane and propofol ischemia-reperfusion-induced renal injury. Renal tubular cell viability was quantitatively assessed by flow cytometry after cell culture and classified as early apoptosis, necrotic cells, and intact cells.

Results: Early apoptosis was significantly higher in isoflurane and propofol anesthetized animals subjected to renal ischemia-reperfusion injury when compared to both cyclosporine A treated and sham groups. Necrosis percentage was significantly higher in propofol-anesthetized animals subjected to renal ischemia-reperfusion injury. The percentage of intact cells was lower in both, isoflurane and propofol anesthetized animals subjected to renal ischemia-reperfusion injury.

Conclusion: In a model of ischemia-reperfusion-induced renal injury, cyclosporine A, $5 \mathrm{~m} \cdot \mathrm{kg}^{-1}$, administered five minutes before renal reperfusion in rats with acute-induced hyperglycemia under either isoflurano or propofol anesthesia, attenuated early apoptosis and preserved viability in renal tubular cells, regardless of the anesthetic used.

Key words: Cyclosporine. Hyperglycemia. Reperfusion Injury. Apoptosis. Kidney. Rats. 


\section{- Introduction}

Acute hyperglycemia is associated with increased morbidity and mortality in patients with trauma, cardiovascular collapse, and those subjected to heart surgery ${ }^{1}$, due to increased oxidative stress in ischemic organs $^{2-4}$.

The choice of anesthetic techniques, with drugs that provide better protection against the effects of ischemia and reperfusion, has been studied particularly in renal transplantation using the general anesthesia technique with propofol or isoflurane ${ }^{5}$.

The mitochondrial permeability transition pore opening occurs within the initial minutes of reperfusion after ischemia and is associated with pathogenesis of necrosis and apoptosis and should be regarded as a determining step for reversible or irreversible cell death6. Inhibition of the mitochondrial permeability transition pore by cyclosporine $A$ at the onset of reperfusion has been shown to protect the myocardium subjected to ischemia ${ }^{7,8}$. Krolikowski et al. ${ }^{9}$ demonstrated that keeping the mitochondrial permeability transition pore closed with cyclosporine A enhanced cardioprotection produced by isoflurane-induced postconditioning. Huhn et al. ${ }^{10}$ assessed the extent of myocardial infarct in rats after ischemia-reperfusion injury and demonstrated that hyperglycemia blocked sevoflurane-induced postconditioning, worsening the injury. They also showed that the inhibition of the mitochondrial permeability transition pore with cyclosporine A was able to reverse the loss of sevoflurane-induced postconditioning and cardioprotection ${ }^{10}$.

Thus, we hypothesized that cyclosporine A could protect the ischemiareperfusion-induced renal injury during transiently hyperglycemia in a rat model under propofol or isoflurane anesthesia. In this study, we proposed to determine the effects of cyclosporine $A$ in hyperglycemic rat kidneys subjected to ischemia-reperfusion injury under the exposition of either propofol or isoflurane.

\section{Methods}

The Institutional Review Board on Animal Experimentation approved this study, protocol \# CEEA 875-2011. We used the ischemia-reperfusion-induced renal injury model similar to other experiments in our laboratory ${ }^{11-13}$.

We randomly divided 36 male Wistar rats (Rattus norvegicus albinus), weighting 250-320 $\mathrm{g}$ into six groups. For the initial instrumentation, all the animals were anesthetized with 3-4\% isoflurane in $100 \%$ inspired fraction of oxygen inside an acrylic compartment. The animals' tracheas were subjected to endotracheal intubation and the animals were mechanically ventilated with a Harvard Rodent Ventilator 683 (Harvard Apparatus, Holliston, Massachusetts, USA). Ventilation was adjusted to deliver tidal volumes of $10 \mathrm{~mL} . \mathrm{kg}^{-1}$ with a respiratory rate of 70-80 breaths. $\mathrm{min}^{-1}$. Further adjustments were made to maintain end-tidal carbon dioxide between 30 to $40 \mathrm{mmHg}$ (Datex, Engstron, Finland). According to the studied group, anesthesia was maintained with isoflurane at $1.5-2 \%$ alveolar concentration in $100 \%$ inspired fraction of oxygen (Ohmeda Excel $210 \mathrm{SE}$ anesthesia apparatus with Isotec 5 Ohmeda vaporizer, GE Healthcare, Chicago, IL, USA) or with propofol $1 \mathrm{mg} \cdot \mathrm{kg}^{-1} \cdot \mathrm{min}^{-1}$ (equivalent to $0.16 \mathrm{mg} \cdot \mathrm{kg}^{-1} \cdot \mathrm{min}^{-1}$ for humans) via an infusion pump $\left(\mathrm{ANNE}^{\circledR}{ }^{\circledR}\right.$ Abbott Laboratories, Lake Bluff, IL, USA). Inspired and expired anesthetic gas concentrations were continuously measured throughout the procedure (Datex, Engstron, Finland). Mean arterial pressure was continuously recorded using a catheter surgically inserted into the left carotid artery and connected to a pressure transducer 
(Datex, Engstron, Finland). The right internal jugular vein was cannulated for fluid (lactated Ringer's solution, $3 \mathrm{ml} . \mathrm{kg}^{-1} \cdot \mathrm{h}^{-1}$ ) and drug administration. After a median laparotomy, all groups were subjected to right nephrectomy. Hyperglycemia was induced in all animals at the trial onset by administration of glucose, 2.5 g. $\mathrm{kg}^{-1}$, via intraperitoneal injection.

The animals were differentiated in six groups, as follows:

- Isoflurane group ( $n=6)$, isofluraneanesthetized animals plus intravenous (IV) injection of normal saline, $1 \mathrm{ml}$, five minutes before renal reperfusion;

- Isoflurane/cyclosporine A group (n = 6), isoflurane-anesthetized animals plus cyclosporine, $5 \mathrm{mg} \cdot \mathrm{kg}^{-1} \mathrm{IV}$, diluted in $1 \mathrm{ml}$ of normal saline, five minutes before renal reperfusion;

- Isoflurane sham group ( $\mathrm{n}=6)$, isoflurane-anesthetized animals and no ischemia-reperfusion-induced renal injury;

- Propofol group $(n=6)$, propofolanesthetized animals plus IV injection of normal saline, $1 \mathrm{ml}$, five minutes before renal reperfusion;

- Propofol/cyclosporine A group (n = 6), propofol-anesthetized animals plus cyclosporine, $5 \mathrm{mg} . \mathrm{kg}-1 \mathrm{IV}$, diluted in $1 \mathrm{ml}$ of normal saline, five minutes before renal reperfusion;

- Propofol sham group $(n=6)$, propofolanesthetized animals and no ischemiareperfusion-induced renal injury.

In thegroups with ischemia-reperfusioninduced renal injury, left kidney was exposed and subjected to ischemia by clamping the renal artery with a microaneurysm clamp for 25 minutes. Cyclosporine $\mathrm{A}, 5 \mathrm{mg} \cdot \mathrm{kg}^{-1}$, or normal saline were injected intravenously five minutes before reperfusion according to the group studied. Rectal temperature was monitored and kept between $37^{\circ}$ and $38^{\circ} \mathrm{C}$ with a warmed jelly blanket.
After the reperfusion, the vascular catheters were removed, surgical wounds were infiltrated with $0.25 \%$ bupivacaine and were sutured. Analgesia was also provided with subcutaneous injection of buprenorphine, $0.05 \mathrm{mg} . \mathrm{kg}^{-1}$. The anesthetic administration was interrupted, the tracheal tubes were removed and the animals were maintained in the animals' cages and were provided with standard rat chow and water ad libitum.

After 24 hours, the animals were anesthetized with isoflurane as previously described, a median laparotomy was performed and the left kidney was removed for analysis. The animals under isoflurane anesthesia were then euthanized.

\section{Cell viability (apoptosis) assessment}

After removal, the left kidney was placed in an appropriate culture to assess cell viability by flow cytometry ${ }^{14}$. The viability of the cells (initial apoptotic process, necrotic cells, and intactcells) was quantitatively determined (percentage of initial apoptosis and viable cells). We used an apoptosis detection kit consisting of annexin V-FITC and propidium iodide (Pharmingen ${ }^{\circledR}$, Becton, Dickinson and Company, San Jose, CA, USA $)^{15}$. The assessments were performed using a FACSCalibur ${ }^{\circledR}$ flow cytometer (Becton, Dickinson and Company, San Jose, CA, USA), consisting of three fluorescence detectors via CellQuest ${ }^{\circledR}$ and Paint-a-gate ${ }^{\circledR}$ software (Becton, Dickinson and Company, San Jose, CA, USA). Blinded technicians to the groups studied performed flow cytometric analyses.

\section{Statistics}

Flow cytometry data was assessed using analysis of variance in a completely randomized design, followed by Tukey's test for multiple comparisons between means. Mean arterial pressure was submitted to two-way (groups and measurement occasions interactions) 
repeated measures analysis of variance followed by Student-Newman-Kuels post hoc tests. The significance level was set at 0.05 .

\section{- Results}

The values of mean arterial pressure are shown in Table 1, according to the groups studied and measurement occasions. The values of mean arterial pressure were not statistically different among groups and measurement occasions $(p>0.05)$. The values of blood glucose levels are shown in Table 2, according to the groups studied and measurement occasions. Intraperitoneal injection of glucose was equally effective in causing a transient hyperglycemia in all groups studied. The percentages of initial (early) apoptosis, dead tubular cells and intact tubular cells are shown in Table 3. The groups anesthetized with either isoflurane or propofol and treated with cyclosporine $A$ exhibited a marked and statistically $(p<0.001)$ reduction of early apoptosis, when compared to non-treated groups. Non-treated propofol anesthetized animals presented with a higher percentage of dead tubular cells $(p<0.001)$ and percentage of intact tubular cells was lower in both non-treated propofol and isoflurane groups $(p<0.001)$.

Table 1 - Mean arterial pressure $(\mathrm{mmHg})$ at selected measurement occasions according to the groups studied. Values are shown as mean + standard deviation.

\begin{tabular}{lccc} 
Groups & Baseline & $\begin{array}{c}\text { After hyperglycemia } \\
\text { induction }\end{array}$ & $\begin{array}{c}\text { Immediately after } \\
\text { renal ischemia } \\
\text { induction }\end{array}$ \\
\hline Isoflurane $(\mathrm{n}=6)$ & $94.5+16.1$ & $92.0+17.9$ & $95.8+20.1$ \\
Isoflurane/cyclosporine A $(\mathrm{n}=6)$ & $106.1+5.9$ & $97.7+15.6$ & $107.0+10.9$ \\
Isoflurane sham $(\mathrm{n}=6)$ & $90.5+27.2$ & $95.7+15.8$ & $93.5+23.5$ \\
Propofol $(\mathrm{n}=6)$ & $99.2+3.3$ & $92.0+16.9$ & $94.7+19.2$ \\
Propofol/cyclosporine A $(\mathrm{n}=6)$ & $101.7+20.8$ & $106.0+14.7$ & $110.7+12.9$ \\
Propofol sham $(\mathrm{n}=6)$ & $105.5+17.2$ & $110.2+20.0$ & $87.5+29.4$ \\
\hline
\end{tabular}

Table 2 - Blood glucose levels (mg.dL-1) at selected measurement occasions according to the groups studied. Values are shown as mean + standard deviation.

\begin{tabular}{lccc} 
Groups & Baseline & $\begin{array}{c}5 \text { minutes after } \\
\text { reperfusion }\end{array}$ & $\begin{array}{c}24 \text { hours after } \\
\text { reperfusion }\end{array}$ \\
\hline Isoflurane $(\mathrm{n}=6)$ & $152.7+38.2$ & $271.0+45.4^{*}$ & $152.0+35.2$ \\
Isoflurane/cyclosporine A $(\mathrm{n}=6)$ & $158.8+33.8$ & $281.8+75.7^{*}$ & $98.4+41.2$ \\
Isoflurane sham $(\mathrm{n}=6)$ & $212.4+48.3$ & $302.5+79.9^{*}$ & $181.2+12.7$ \\
Propofol $(\mathrm{n}=6)$ & $127.6+30.9$ & $259.8+26.2^{*}$ & $130.2+24.1$ \\
Propofol/cyclosporine A $(\mathrm{n}=6)$ & $155.6+32.7$ & $246.9+67.5^{*}$ & $118.7+34.1$ \\
Propofol sham $(\mathrm{n}=6)$ & $180.7+49.0$ & $301.8+42.9^{*}$ & $175.7+16.8$ \\
\hline
\end{tabular}

${ }^{*} \mathrm{p}<0.001$ vs. Baseline and 24 hours after reperfusion. 
Table 3 - Percentages (+ standard deviation) of tubular cells in specimens according to flow cytometric classes in the studied groups.

\begin{tabular}{|c|c|c|c|}
\hline Groups & $\begin{array}{c}\text { Early } \\
\text { apoptosis (\%) }\end{array}$ & $\begin{array}{c}\text { Dead } \\
\text { tubular cells (\%) }\end{array}$ & $\begin{array}{c}\text { Intact } \\
\text { tubular cells (\%) }\end{array}$ \\
\hline Isoflurane $(n=6)$ & $86.3+9.0^{*}$ & $1.8+1.6$ & $10.0+9.3^{¥}$ \\
\hline Isoflurane/cyclosporine A $(n=6)$ & $21.2+17.5$ & $4.2+2.3$ & $72.8+17.8$ \\
\hline Isoflurane sham $(n=6)$ & $9.9+6.6$ & $1.7+2.4$ & $88.4+6.0$ \\
\hline Propofol $(n=6)$ & $79.3+11.4^{\S}$ & $14.5+12.2^{\pi}$ & $4.8+6.2^{\| 1}$ \\
\hline Propofol/cyclosporine A $(n=6)$ & $15.1+11.2$ & $4.0+3.2$ & $73.2+17.7$ \\
\hline Propofol sham $(n=6)$ & $10.3+5.3$ & $1.4+0.7$ & $88.4+4.7$ \\
\hline \multicolumn{4}{|c|}{${ }^{*} \mathrm{p}<0.001$ vs. Isoflurane/cyclosporine A, Isoflurane sham, Propofol/cyclosporine A and Propofol sham groups (within early apoptosis). } \\
\hline \multicolumn{4}{|c|}{${ }^{5} \mathrm{p}<0.001$ vs. Isoflurane/cyclosporine A, Isoflurane sham, Propofol/cyclosporine A and Propofol sham groups (within early apoptosis). } \\
\hline \multirow{2}{*}{\multicolumn{4}{|c|}{$\begin{array}{l}\text { " } p<0.001 \text { vs. Isoflurane, Isoflurane/cyclosporine A, Isoflurane sham, Propofol/cyclosporine A and Propofol sham groups (within dead } \\
\text { tubular cells). }\end{array}$}} \\
\hline & & & \\
\hline \multicolumn{4}{|c|}{$\begin{array}{l}{ }^{*} p<0.001 \text { vs. Isoflurane/cyclosporine A, Isoflurane sham, Propofol/cyclosporine A and Propofol sham groups (within intact tubular } \\
\text { cells). }\end{array}$} \\
\hline \multicolumn{4}{|c|}{$\begin{array}{l}\text { " } p<0.001 \text { vs. Isoflurane/cyclosporine A, Isoflurane sham, Propofol/cyclosporine A and Propofol sham groups (within intact tubular } \\
\text { cells). }\end{array}$} \\
\hline
\end{tabular}

\section{- Discussion}

The most important data in our study were obtained after analyzing cell viability by flow cytometry. There was a lower percentage of apoptotic cells and higher percentage of intact cells in kidneys of cyclosporine A-treated animals.

Male rats were chosen in this study because they are more susceptible to ischemia/reperfusion renal injury ${ }^{16}$. The 25-minute ischemia duration was also used by some authors to cause mild or moderate renal injury 16 and is considered the best ischemia duration that outlines the impact of hyperglycemia ${ }^{17}$. There were no differences in mean arterial pressure values among groups. These results indicate that there was hemodynamic stability during the experimental phases and that the values were suitable for the animals anesthetized with either propofol or isoflurane.

$$
\text { Cyclosporine } A \text { is a potent }
$$
immunosuppressive agent that has been used to prevent graft rejection in liver, heart and kidney transplantation for more than 30 years $^{18}$. Nonetheless, its efficacy as an immunosuppressive agent was damped by several associated side effects, including renal toxicity ${ }^{19}$. These problems were attributed to the high doses initially used and were substantially improved after lowering the dose for solid organ transplantation.

Cyclosporine $A$ is considered to inhibit mitochondrial permeability transition pore opening by preventing the binding of cyclophilin $\mathrm{D}$ to the adenine nucleotide translocase. The mitochondrial permeability transition pore opening, triggered by mitochondrial calcium overload and overproduction of reactive oxygen species, plays a central role in severe and even lethal reperfusion injury ${ }^{20}$.

Considering the effects of both acute and chronic hyperglycemia on the preconditioning protection in heart and renal tissues, its been demonstrated that it attenuates or even abolishes the protective effects afforded by either ischemic ${ }^{21}$ or 
pharmacological preconditioning 22,23 .

Lemoine et $a .^{24}$, in a non-induced hyperglycemia model of renal ischemiareperfusion injury in mice, showed that cyclosporine A, $3 \mathrm{mg} \cdot \mathrm{kg}^{-1}$, administered 5 minutes before the end of the ischemia was able to protect the kidneys against the ischemiareperfusion insult. In their experimental model, cyclosporine A not only attenuated renal injury (verified by a histological score and apoptosis markers) but also limited mortality, similarly to what they observed with the ischemic postconditioning protection ${ }^{24}$. A new finding in our study was that cyclosporine A was able to attenuate the renal ischemia-reperfusion injury in conditions of hyperglycemia.

We may consider the dose of cyclosporine A used in our study low when compared to the higher doses used in the rat to study renal hemodynamic, which were up to $40 \mathrm{mg} \cdot \mathrm{kg}^{-125,26}$. Cyclosporine $A$ is a potential nephrotoxic drug that decreases renal blood flow and increases renal vascular resistance ${ }^{27}$. Its toxicity is dose-dependent and, as previously shown, lower doses are effective in postconditioning renal protection against ischemia-reperfusion ${ }^{24}$ and should be preferable for this purpose.

The mechanisms responsible for apoptosis after the ischemia-reperfusioninjury episode are attributed to increased endonuclease activity, increased calcium entry into the cell, or release of reactive oxygen species. Reactive oxygen species induce apoptosis, causing damage to deoxyribonucleic acid, oxidation of lipid membranes, and/or direct activation and expression of genes/ proteins responsible for apoptosis. Chien et $a .^{28}$ demonstrated that reactive oxygen species are produced in significant quantities in the epithelium of proximal tubules during reperfusion and may be responsible for cell apoptosis. However, unlike proximal tubule cells, other mechanisms than the formation of reactive oxygen species may prevail in induced apoptosis in distal tubule epithelial cells from kidneys subjected to ischemia-reperfusioninjury. Treatment with superoxide dismutase and other free radical scavengers may be effective in preventing apoptosis mediated by reactive oxygen species in proximal tubule cells. Analysis of apoptosis levels by flow cytometry showed differences in percentage of initial apoptosis between both, isoflurane and propofol ischemia-reperfusion-induced injury and the other groups, indicating that cyclosporine A was able to restore protection, regardless the anesthetic used.

The model studied, with 25-minute ischemia duration followed by reperfusion, did not produce statistically significant levels of cell necrosis in the groups studied, except by the propofol anesthetized animals. This result differs from the results of a previous study of our group comparing the effects of propofol and isoflurane on renal ischemia-reperfusioninjury during transient hyperglycemia when we observed no differences on the percentage of dead tubular cells between isoflurane and propofol $^{13}$.

The percentage of intact cells was higher in sham groups and in the cyclosporine A treated groups. Renal injury associated with ischemia-reperfusion is a result of a dynamic process, involving a complex interaction between the vasculature and renal tubules. The events that modulate the vasculature alter the supply of oxygen and nutrients to epithelial cells and damaged epithelial cells respond with production of autocrine factors, affecting their own survival, whereas paracrine factors affect the vasculature. The signaling cascade is then activated, resulting in hemodynamic changes, leukocytosis, and direct injury to the tubular epithelial cells, followed by a repair process that may restore morphology and function ${ }^{29}$.

\section{- Conclusions}

In the model of ischemia-reperfusioninduced renal injury, cyclosporine $\mathrm{A}, 5 \mathrm{~m} \cdot \mathrm{kg}^{-1}$, administered five minutes before renal reperfusion 
in rats with acute-induced hyperglycemia under either isoflurano or propofol anesthesia, and considering classification of cells by flow cytometry, attenuated early apoptosis and preserved viability in renal tubular cells, regardless of the anesthetic used.

\section{References}

1. Ouattara A, Lecomte $P$, Le Manach $Y$, Landi $M$, Jacqueminet $S$, Platonov I, Bonnet N, Riou B, Coriat P. Poor intraoperative blood glucose control is associated with a worsened hospital outcome after cardiac surgery in diabetic patients. Anesthesiology. 2005 Oct;103(4):687-94. PMID: 16192760.

2. Esposito K, Nappo F, Marfella R, Giugliano G, Giugliano F, Ciotola M, Quagliaro L, Ceriello A, Giugliano D. Inflammatory cytokine concentrations are acutely increased by hyperglycemia in humans: role of oxidative stress. Circulation. 2002 Oct 15;106(16):2067-72. PMID: 12379575.

3. Podrazik RM, Natale JE, Zelenock GB, D'Alecy LG. Hyperglycemia exacerbates and insulin fails to protect in acute renal ischemia in the rat. J Surg Res. 1989 Jun;46(6):572-8. PMID: 2659896.

4. Moursi M, Rising CL, Zelenock GB, D’Alecy LG. Dextrose administration exacerbates acute renal ischemic damage in anesthetized dogs. Arch Surg. 1987 Jul;122(7):790-4. PMID: 3592969.

5. Babacan A, Ayhan G, Akcabay M, Olgay G, Ozturk E. Assessment of total intravenous anesthesia in renal transplantation. Transplant Proc. 1998 May;30(3):750-3. PMID: 9595083.

6. Crompton M. The mitochondrial permeability transition pore and its role in cell death. Biochem J. 1999 Jul 15;341(Pt 2)233-49. PMID: 10393078.

7. Hausenloy DJ, Maddock HL, Baxter GF, Yellon DM. Inhibiting mitochondrial permeability transition pore opening: a new paradigm for myocardial preconditioning? Cardiovasc Res. 2002 Aug 15;55(3):534-43. PMID: 12160950.

8. Argaud L, Gateau-Roesch O, Raisky O, Loufouat J, Robert D, Ovize M. Postconditioning inhibits mitochondrial permeability transition. Circulation. 2005 Jan 18;111(2):194-7. PMID: 15642769.
9. Krolikowski JG, Bienengraeber M, Weihrauch D, Warltier DC, Kersten JR, Pagel PS. Inhibition of mitochondrial permeability transition enhances isoflurane-induced cardioprotection during early reperfusion: the role of mitochondrial KATP channels. Anesth Analg. 2005 Dec;101(6):1590-6. PMID: 16301224.

10. Huhn R, Heinen A, Weber NC, Hollmann MW, Schlack W, Preckel B. Hyperglycaemia blocks sevoflurane-induced postconditioning in the rat heart in vivo: cardioprotection can be restored by blocking the mitochondrial permeability transition pore. $\mathrm{Br} \mathrm{J}$ Anaesth. 2008 Apr;100(4):465-71. PMID: 18305078.

11. Vianna PT, Castiglia YM, Braz JR, Viero RM, Beier S, Vianna Filho PT, Vitoria A, Reinoldes Bizarria Guilherme G, de Assis Golim M, Deffune $E$. Remifentanil, isoflurane, and preconditioning attenuate renal ischemia/ reperfusion injury in rats. Transplant Proc. 2009 Dec;41(10):4080-2. PMID: 20005344.

12. Caetano AM, Vianna Filho PT, Castiglia YM, Golim MA, de Souza AV, de Carvalho LR, Deffune E, de Oliveira C, Vianna PT. Erythropoietin attenuates apoptosis after ischemia-reperfusion-induced renal injury in transiently hyperglycemic Wister rats. Transplant Proc. 2011 Dec;43(10):3618-21. PMID: 22172815.

13. Carraretto AR, Vianna Filho PT, Castiglia YM, Golim Mde A, Souza AV, Carvalho LR, Deffune E, Vianna PT. Dos propofol and isoflurane protect the kidney against ischemia/reperfusion injury during transient hyperglycemia? Acta Cir Bras. 2013 Mar;28(3):161-6. PMID: 23503855.

14. Vermes I, Haanen C, Steffens-Nakken $\mathrm{H}$, Reutelingsperger C. A novel assay for apoptosis. Flow cytometric detection of phosphatidylserine expression on early apoptotic cells using fluorescein labelled Annexin V. J Immunol Methods. 1995 Jul 17;184(1):39-51. PMID: 7622868.

15. Seaton BA, Dedman JR. Annexins. Biometals. 1998 Dec;11(4):399-404. PMID: 10191502.

16. Park KM, Kim JI, Ahn Y, Bonventre AJ, Bonventre JV. Testosterone is responsible for enhanced susceptibility of males to ischemic renal injury. J Biol Chem. 2004 Dec 10;279(50):52282-92. PMID: 15358759.

17. Hirose R, Xu F, Dang K, Liu T, Behrends M, Brakeman PR, Wiener-Kronish J, Niemann 
CU. Transient hyperglycemia affects the extent of ischemia-reperfusion-induced renal injury in rats. Anesthesiology. 2008 Mar;108(3):402-14. PMID: 18292678.

18. Knops N, Levtchenko $E$, van den Heuvel B, Kuypers D. From gut to kidney: transporting and metabolizing calcineurin-inhibitors in solid organ transplantation. Int J Pharm. 2013 Aug 16;452(1-2):14-35. PMID: 23711732.

19.Cattaneo D, Perico N, Gaspari F, Remuzzi G. Nephrotoxic aspects of cyclosporine. Transplant Proc. 2004 Mar;36(2 Suppl):234S9S. PMID: 15041344.

20. Gomez L, Li B, Mewton N, Sanchez I, Piot C, Elbaz M, Ovize M. Inhibition of mitochondrial permeability transition pore opening: translation to patients. Cardiovasc Res. 2009 Jul 15;83(2):226-33. PMID: 19221132.

21. Kersten JR, Toller WG, Gross ER, Pagel PS, Warltier DC. Diabetes abolishes ischemic preconditioning: role of glucose, insulin, and osmolality. Am J Physiol Heart Circ Physiol. 2000 Apr;278(4):H1218-24. PMID: 10749717.

22. Wang $H$, Chen $H$, Wang $L$, Liu L, Wang M, Liu X. Acute hyperglycemia prevents dexmedetomidine-induced preconditioning against renal ischemia-reperfusion injury. Acta Cir Bras. 2014 Dec;29(12):812-8. PMID: 25517495.

23. Canfield SG, Sepac A, Sedlic F, Muravyeva MY, Bai X, Bosnjak ZJ. Marked hyperglycemia attenuates anesthetic preconditioning in human-induced pluripotent stem cellderived cardiomyocytes. Anesthesiology.
2012 Oct;117(4):735-44. PMID: 22820846.

24. Lemoine $S$, Pillot $B$, Rognant N, Augeul L, Rayberin $M$, Varennes $A$, Laville $M$, Ovize $M$, Juillard L. Postconditioning with cyclosporine a reduces early renal dysfunction by inhibiting mitochondrial permeability transition. Transplantation. 2015 Apr;99(4):717-23. PMID: 25793558.

25. Bagnis C, Deray G, Dubois M, Jacquiaud C, Bitker MO, Jacobs C. Prevention of acute cyclosporin nephrotoxicity by verapamil and atrial natriuretic factor in the rat. Nephrol Dial Transplant. 1994;9(8):1143-8. PMID: 7800215.

26. Murray BM, Paller MS, Ferris TF. Effect of cyclosporine administration on renal hemodynamics in conscious rats. Kidney Int. 1985 Nov;28(5):767-74. PMID: 3910916.

27. Weir MR, Klassen DK, Shen SY, Sullivan D, Buddemeyer EU, Handwerger BS. Acute effects of intravenous cyclosporine on blood pressure, renal hemodynamics, and urine prostaglandin production of healthy humans. Transplantation. 1990 Jan;49(1):41-7. PMID: 2301025.

28. Chien CT, Chen CF, Hsu SM, Lee PH, Lai MK. Protective mechanism of preconditioning hypoxia attenuates apoptosis formation during renal ischemia/reperfusion phase. Transplant Proc. 1999 Aug;31(5):2012-3. PMID: 10455957.

29. Bonventre JV, Weinberg JM. Recent advances in the pathophysiology of ischemic acute renal failure. J Am Soc Nephrol. 2003 Aug;14(8):2199-210. PMID: 12874476.

\section{Correspondence:}

Pedro Thadeu Galvão Vianna

Departamento de Anestesiologia

Faculdade de Medicina de Botucatu, UNESP

Distrito de Rubião Jr, s/n

18618-970 Botucatu - SP Brasil

Tel.: (55 14)3882-1414

ptgv@me.com

Received: Nov 19, 2016

Review: Jan 17, 2017

Accepted: Feb 21, 2017
Conflict of interest: none

Financial source: FAPESP

\begin{abstract}
${ }^{1}$ Research performed at Department of Anesthesiology, Botucatu Medical School, Universidade Estadual de São Paulo (UNESP), Botucatu-SP, Brazil. Part of PhD degree thesis, Postgraduate Program in Anesthesiology. Tutor: Pedro Thadeu Galvão Vianna.
\end{abstract}

